\title{
La necesaria dinamización de la producción científica en el ámbito de las humanidades y el patrimonio cultural
}

\author{
Salomé Lendínez Ramírez | alacaja.com \\ URL de la contribución <www.iaph.es/revistaph/index.php/revistaph/article/view/4676>
}

La producción científica es prolífica y crece a un ritmo irrefrenable, esta afirmación es evidente. Su adecuada gestión y transferencia a la sociedad, las claves para su éxito. La generalización y estandarización de los formatos digitales y la necesidad de su preservación han generado e impuesto la creación y afianzamiento de los repositorios institucionales; la inmensa mayoría de universidades e instituciones científicas en todo el planeta y de toda especialización cuenta con el suyo propio o pertenece a una comunidad que les apoya en este sentido. Podríamos poner innumerables ejemplos de repositorios científicos de acceso abierto como el caso de Digital. CSIC en España o el de la Cornell University (arxiv.org) de Estados Unidos.

Como apunta la coordinadora de este debate, Remedios Melero en su texto de presentación (pp. 58-59), en una situación ideal todos estos repositorios serían de carácter abierto y estarían integrados en uno o varios recolectores de datos a nivel mundial. Gracias a los metadatos asignados a cada artículo o estudio podríamos acceder al conocimiento científico garantizando la calidad de los datos que recibimos, pero existen varios argumentos que impiden que esta situación sea una realidad. Por un lado, el acceso abierto cuenta con la modalidad conocida como la vía verde (green access) o el autoarchivo en los repositorios sin contrastar por pares; si bien es gratuita y se promueve, no garantiza una información, datos y resultados científicos de calidad. En segundo lugar, las reticencias de autores e instituciones y los intereses legítimos de empresas dedicadas a la gestión de la información y de estos volúmenes de datos se constituyen como los tres agentes que impiden la accesibilidad y gratuidad del acceso de forma generalizada, creando unos resultados científicos "free" y otros "premium" desde su concepción.

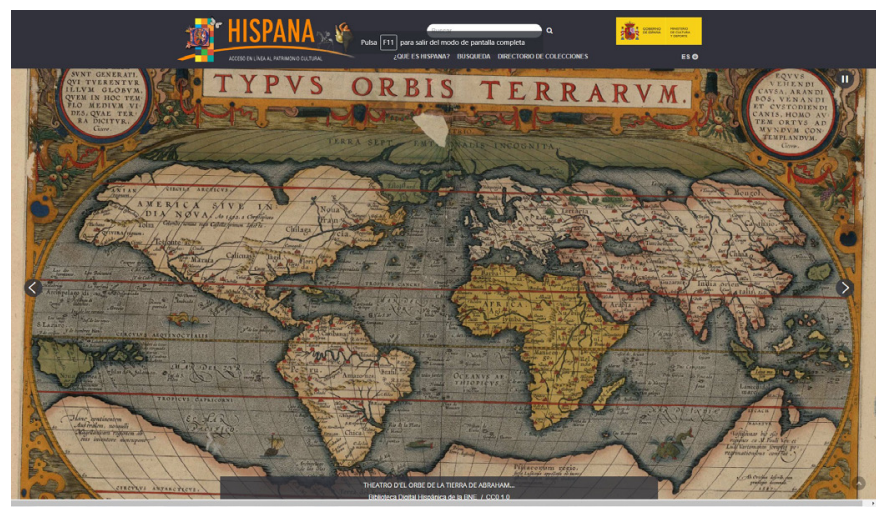

Página de inicio de Hispana

La concentración de agregadores nacionales o por intereses, en definitiva, el establecimiento de grandes grupos de trabajo, podría constituir en sí mismo un problema si no se gestiona de forma objetiva y con parámetros bien establecidos apareciendo cuestiones como la censura o la parcialidad no justificada.

Con esta situación de dualidad en la transferencia del conocimiento científico, las redes sociales académicas son una clara opción para constituirse como ese recolector universal de intereses que acerca la producción científica a las personas interesadas e investigadores de cualquier temática y no al revés como estaría sucediendo en la era predigital.

En el ámbito de las humanidades y el patrimonio cultural, y sobre todo, en el que nosotros mejor conocemos, el de los archivos, nos encontramos con ejemplos a seguir para la divulgación de la producción científica en portales recolectores como Hispana, un portal web creado por el Ministerio de Cultura que reúne las colecciones digitales de archivos, bibliotecas y museos españoles, y el agregador nacional de contenidos al portal de Europeana. 
a debate Repositorios y redes sociales académicas para la transferencia del conocimiento abierto

| coordina Remedios Melero Melero

En Hispana encontramos repositorios digitales como el del Banco de España, de la gran mayoría de universidades (artículos y publicaciones científicas en acceso abierto), de los fondos digitalizados de archivos generales, provinciales o municipales, museos y bibliotecas. Se constituye como un conjunto de colecciones pertenecientes a instituciones culturales y universitarias que, gracias a la normalización de sus formatos y su accesibilidad intuitiva, hacen de este portal un muy acertado y completo recolector de la producción científica en el ámbito cultural en España con más de 200 repositorios institucionales de acceso abierto disponibles.

Desde Hispana, los contenidos se hacen transferibles a Europeana, el agregador de contenidos culturales y patrimoniales a nivel europeo que, como reza en su propia definición, "pertenecen a miles de archivos, bibliotecas y museos para compartir la herencia cultural con fines de educación, investigación y disfrute. Se proporciona acceso a más de 50 millones de archivos digitalizados -libros, música, material gráfico, etc.- y cuenta con sofisticadas herramientas de búsqueda y filtrado para ayudarte a encontrar lo que buscas".

No es un portal de almacenamiento de producción científica en exclusiva, pero sí puede ser considerado un modelo a seguir según el cual, de una forma intuitiva y sencilla, son localizables tanto documentos digitalizados en archivos (fuente primaria para la investigación en todos los campos, no solo el histórico-cultural) como productos científicos en el ámbito cultural, ya que se organizan y presentan de forma temática, agrupando fondos según intereses o motivos concretos (efemérides, materias,etc.).

Ambos ejemplos son dos agregadores que cuentan con una dimensión social y entornos amigables que acercan las fuentes primarias y la producción científica aplicando las metodologías y concepciones de las redes sociales aproximando en definitiva la ciencia cultural y patrimonial a la sociedad, bien al público en general como al profesional. Es esta dirección la que deberemos tomar como "auto-divulgadores" de nuestra profesión y especialidad para que la disciplina científica a la que pertenezcamos y la producción científica que consigamos publicar no quede clasificada como literatura gris en repositorios de alto coste para las universidades o instituciones y sea accesible y atractiva para colegas y organismos afines y para la sociedad que, al fin y al cabo, es el último destinatario de nuestro trabajo.

A modo de conclusión, gracias a los ejemplos que he presentado, puedo afirmar que el acceso abierto y digital de la producción científica en las humanidades a través de repositorios y agregadores de contenidos es la base de la transferencia de conocimientos, pero de nada servirá una gran arquitectura de un sistema complejo de almacenes virtuales sin un objetivo, sin una ruta que le acerque a la sociedad.

Y la ciudadanía y la comunidad científica, ambas, se encuentran en las redes sociales, no solo en las de carácter académico, sino en las genéricas; son perfiles de usuario acostumbrados a sindicarse a contenidos de su interés, a las imágenes y a formatos breves de contenidos. Son estas las características que repositorios, agregadores y redes sociales académicas deben incluir en sus configuraciones para hacer atrayente la producción científica, un reto del que estamos siendo conscientes y del que tenemos mucho que aprender.

Porque como podemos leer en el portal web de Redalyc, (agregador académico en acceso abierto de la actividad científica editorial de Iberoamérica promovido por la Universidad Autónoma de México) "la ciencia que no se ve, no existe". 